\title{
AN EXAMPLE OF THE USE OF BOULDER COUNTING IN LITHOLOGIC MAPPING
}

\author{
Tapani Mutanen
}

\begin{abstract}
Mutanen, Tapani 1971: An example of the use of boulder counting in lithologic mapping. Bull. Geol. Soc. Finland 43, 131-140.

Results of 357 boulder counts from the Ylivieska area, Western Finland, are presented. They provide both new and supplementary information on the bedrock lithology and glacial geology of the area. The results suggest that the method could be routinely used in connection with lithologic mapping in poorly exposed glaciated terrain.
\end{abstract}

Tapani Mutanen, Oy Malminetsijä Ab, Jyväskylä, Finland.

\section{Introduction}

The observation made of the lithology of till is commonly used in the study of ice movement. Usually indicators are checked and indicator fans constructed. This procedure is customary also in prospecting in glaciated terrain. Attempts at locating occurrences of (mostly uncommon) rocks by stone or boulder counting have also been made (e.g. Edelman 1951; Andersson 1964); and a fairly common practice in geologic mapping is to identify unexposed lithologic units, indicated by geophysical anomalies, by observing ice-transported fragments downstream.

Drawing geologic maps for poorly exposed areas is often a matter of fantasy. Now observations made of the lithologic composition of till have revealed the generally short transport distance of the drift material, particularly for the coarsest fractions. Might this fact prove helpful in lithologic mapping - not only to locate the apexes of boulder fans, but even to delimit lithologic units more precisely? This particular question was not in my mind, when I made the first boulder count in Ylivieska. This count, made about $2 \mathrm{~km} \mathrm{E}$ of the supposed $\mathrm{W}$-contact of the Ylivieska gabbro intrusive, gave no basic or ultrabasic boulders, indicating that the contact must lie farther $\mathrm{E}$ than drawn by Salli (1955). Further counts confirmed the situation. Thus the area critical for the occurrence of nickel-copper ores, associated with the gabbro intrusive, diminished quite appreciably.

In the following account, the results of 357 boulder counts are compared to the bedrock lithology, and their glacial geologic implications are discussed.

\section{Bedrock of the area}

The area in question is situated in Central Pohjanmaa, Western Finland. Its Precambrian bedrock was last mapped, on a smaller scale than 
now, by Salli (1955, 1961). In connexion with the prospecting work carried out by the company Oy Malminetsijä Ab during the years 1965-68, I mapped the Ylivieska gabbro intrusive and surrounding areas in detail (Fig. 1). The dominant lithologic element, the gabbro intrusive is bordered by biotite- and quartz-bearing (hybrid?) gabbro-diorite on all sides, except the SW part, where ultramafic differentiates (dunites, peridotites, plagioperidotites and pyroxenites) occur. Small diorite satellites and uralite porphyrite lenses are met with near the intrusive, within schists. The latter include metagraywackes, metapelites and some polymict conglomerates Acid igneous rocks are represented by granodiorites and granodiorite porphyries $\mathrm{E}$ and $\mathrm{NE}$ of the mafic intrusive. Glacial till of variable thickness covers the bedrock. No glaciofluvial deposits are found.

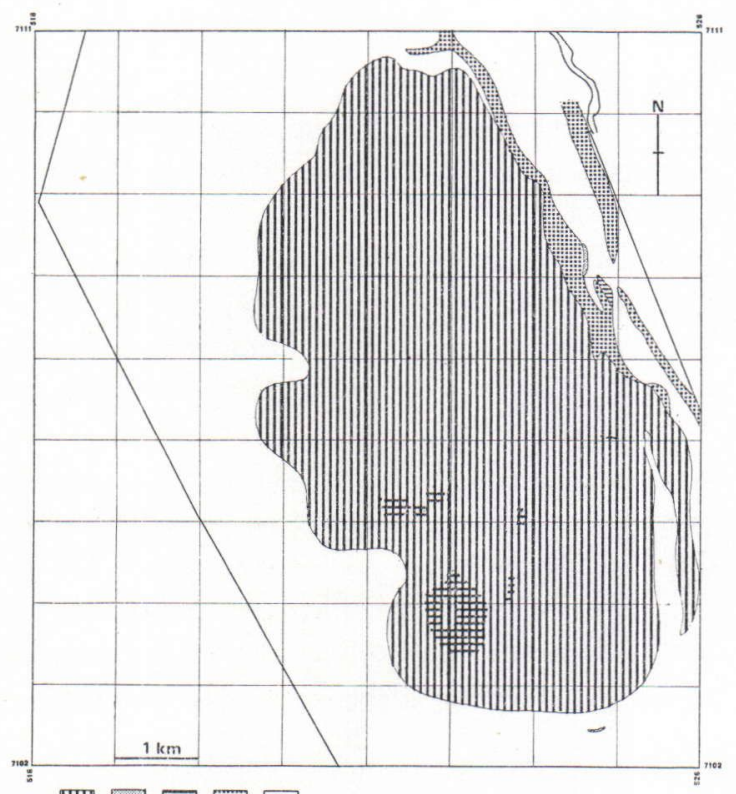

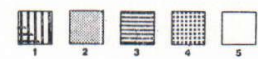

Fig. 1. Simplified lithologic map of the Ylivieska gabbro intrusive and adjoining areas. $1=$ ultrabasics (crossed), gabbros and diorites, $2=$ diorites outside the main intrusive, $3=$ uralite porphyrite, $4=$ acid igneous rocks, $5=$ metasedimentary schists.

\section{Counting}

In investigations of this kind boulders are usually rejected and only stones $(\varnothing 2-20 \mathrm{~cm}$ ) or smaller fractions counted (e.g. Andersson 1964; Gillberg 1965). Edelman (1951) used boulders, because these as a rule are of more local character than finer fractions. In planning the counting, my purpose, too, was to filter out the long-distance material, therefore only boulders $(\varnothing>20 \mathrm{~cm})$ were accepted. The counting method used is neither relative nor absolute in the sense of Lunqvist's definition (Lundqvist 1935, pp. 16-17). In order to minimise the effect caused on the percentage figures by the greater number of the longdistance boulders and the volume of accidental big boulders, each boulder was given a weigh number, from 1 for small boulders (about $20-50 \mathrm{~cm}$ in diameter) to $4-5$ for huge erratics. The isopleths for each rock group are drawn on the basis of these weighed percentage values. Blocky moraine surfaces, diggings, boulder depressions etc. were used as counting sites. At each site 50-150 boulders were counted. After the first promising results I enlarged the counting point net to cover an area of $50 \mathrm{~km}^{2}$.

The point density is highest (10-15 points/ $\mathrm{km}^{2}$ ) over the western-southwestern contact zone of the gabbro intrusive. Other counting sites are equally distributed throughout the area.

For ordinary mapping purposes the net here was rather too dense. It is, however, difficult to choose in advance the optimum density, which naturally depends on the purpose of the work, details required, complexity of the lithology, size of the units to be resolved, nature of the glacial transport and so on. In any case, the denser the net, the more information is obtained, and the less serious is the influence of errors and unrepresentative counts.

\section{Boulder distribution maps and their interpretation}

What makes this area suitable for this kind of investigation is the possibility of testing the 
boulder distribution data by means of the bedrock lithology, known from well over 1000 exposures. Otherwise such laborious work would not have been required, and a much smaller number of counts would well have sufficed.

First I arranged the rock types into groups, easily identifiable in field, as: diorites, gabbros, plagioperidotites, (non-feldspathic) ultrabasic rocks, plagioclase porphyrites, uralite porphyrites, acid igneous rocks, acid/basic tuffites, quartzites and quartz-feldspar schists, metagraywackes etc. Many errors in identification must have occurred, especially in separating gabbros from diorites and mica schists from metagraywackes. To distinguish the various gabbros was hopeless: On the other hand, refinement in the group, comprising acid igneous rocks could easily have been effected.

The form and extent of the gabbro intrusive is clearly shown by the distribution of ultrabasic plus basic boulders (Fig. 2). In drawing the isopleths, 5 per cent was allowed for background.

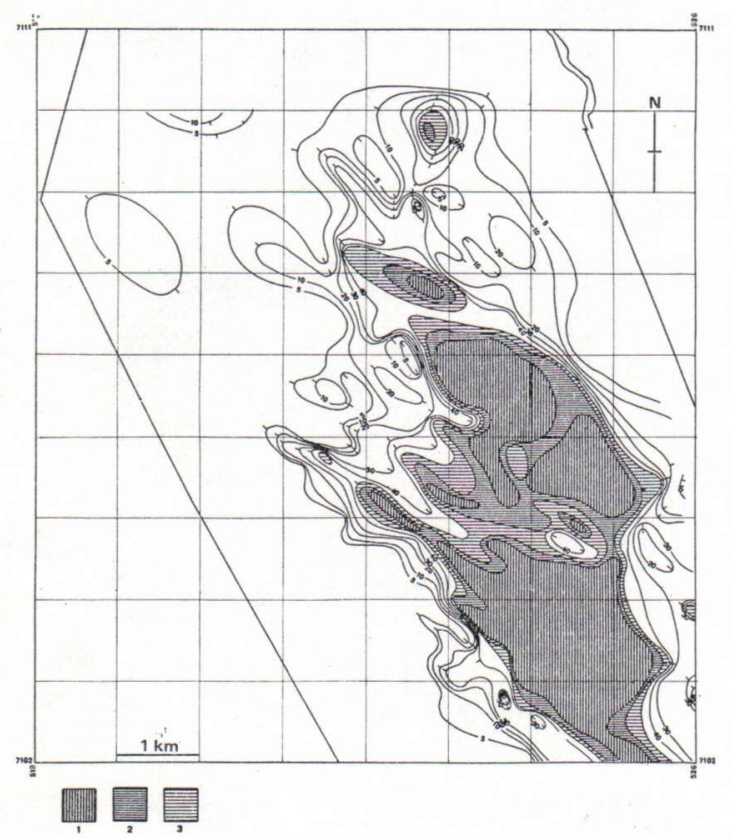

Fig. 2. Distribution of ultrabasic plus gabbro boulders in till (in weighed percentages). $1=>70 \%, 2=70-$ $60 \%, 3=60-50 \%$, lower isopleths marked by numbers.

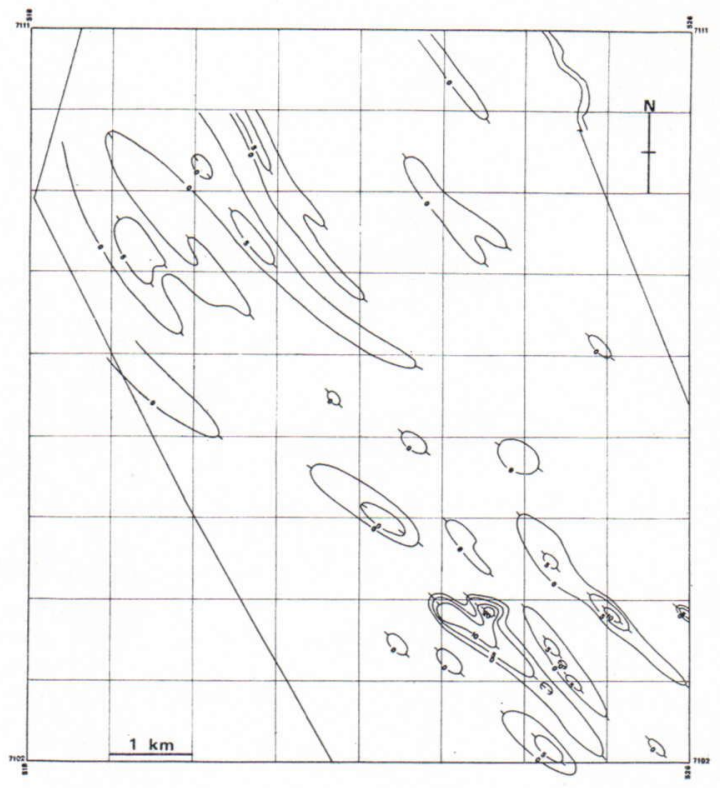

Fig. 3. Distribution of ultrabasic boulders in till.

Separate anomalies in the NW part of the area, likewise the NW-pointing tongue from the main anomaly, are due to boulders derived from outside the area. The course of the W contact of the intrusive is inferred from the basicultrabasic boulders. Given cautious interpretation, even details can be drawn. Low-percentage tongues, splitting the main anomaly, as well as asymmetrical features on its western margin, contain interesting glacial geologic information (pp. 136-137).

Possibly all the ultrabasic boulders, forming the northern group of anomalies (Fig. 3), have their provenance outside the large gabbro intrusive. The southern group denotes ultrabasic rocks, belonging to the gabbro intrusive as early differentiates. Being more sensitive to chemical weathering than the surrounding rocks, the ultrabasics are deeply denuded, exposed nowhere. Their occurrence was first indicated by qualitative boulder mapping, and subsequently proved by numerous drill holes.

The main reasons for the neat appearance of the plagioperidotite boulder fans (Fig. 4) are the restricted area of occurrence of this rock type 


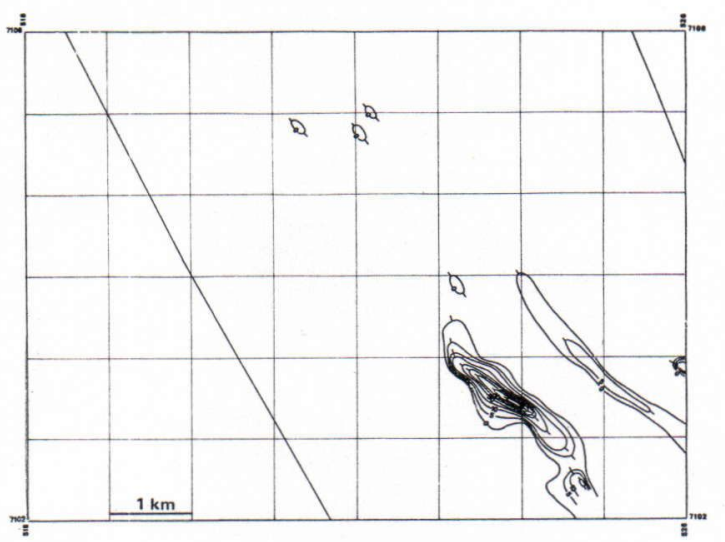

Fig. 4. Distribution of plagioperidotite boulders in till.

and the characteristic spotted surface of the boulders, making identification easy. Comparison of the symmetries of the plagioperidotite fans with those of the ultrabasic boulder fans reveals that ultrabasic boulders wear down more quickly during transport than do the tougher and less fracturable plagioperidotite boulders

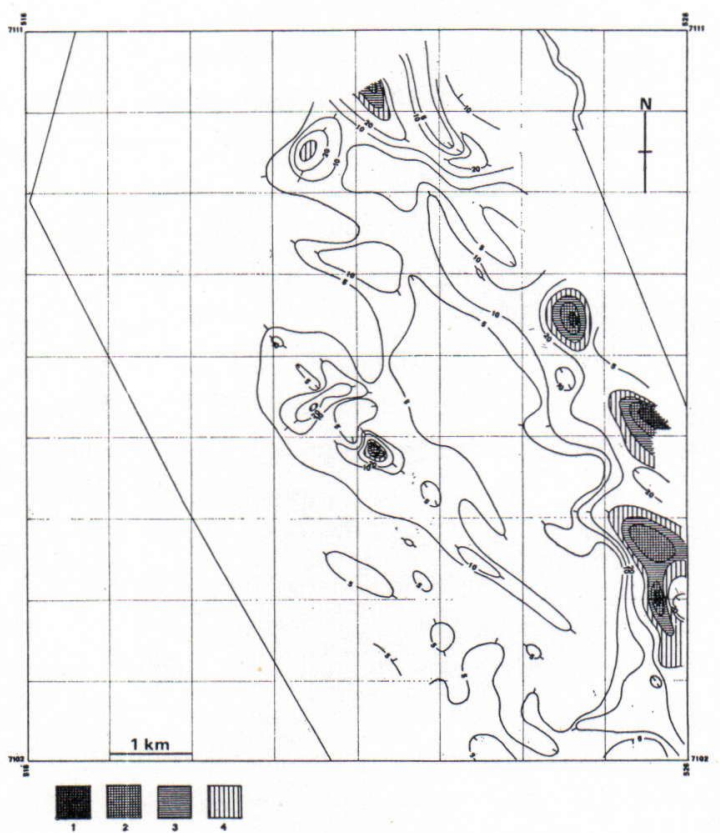

Fig. 5. Distribution of diorite boulders in till. $1=>60 \%$, $2=60-50 \%, 3=50-40 \%, 4=40-30 \%$. (cf. Holmes 1952, p. 1 003). It is seen, if we compare Figs. 3. and 4 with other distribution maps, that the best resolution is obtained with rock types which are easy to identify and of which the proportion of boulders is moderately low. Again a slight asymmetry in the westernmost plagioperidotite fan can be noted.

The apexes of the fans of ultrabasic and plagioperidotite boulders indicate the places where the lowest horizons of the differentiated and subsequently folded intrusive sheet meet the present erosion surface. From the distribution of the diorite boulders, again, the position of the upper horizon of the intrusive can be deduced (Fig. 5). Rock types, counted as diorites differ from typical gabbros in bearing macroscopic biotite and white plagioclase on the weathered surface. In fact a good many of them are true gabbros; nevertheless they mark the more acid, uppermost differentiates of the intrusive. Lack of diorite boulders in the SW part of the intrusive is in harmony with the

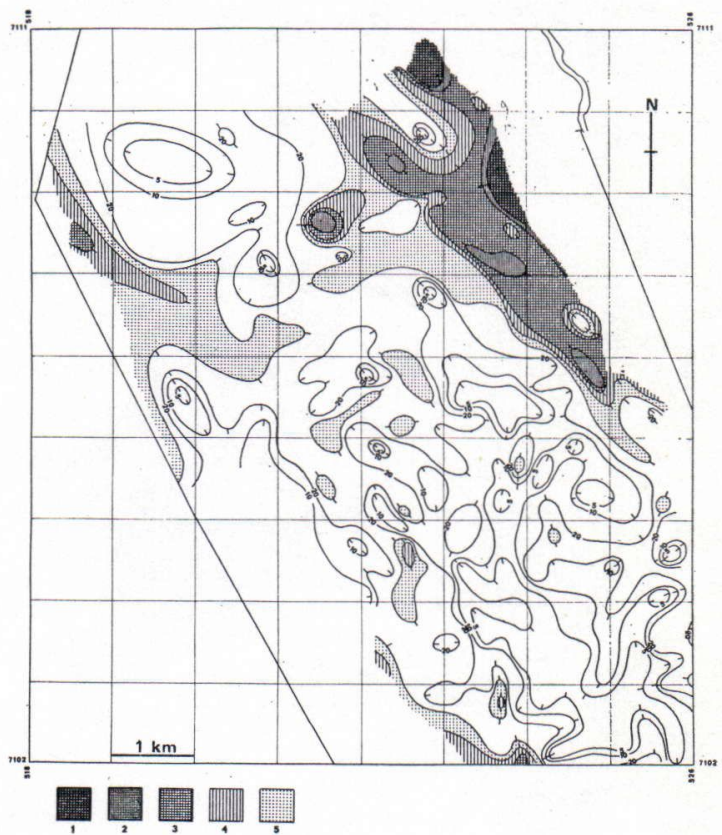

Fig. 6. Distribution of boulders of acid igneous rocks in till. $1=>70 \%, 2=70-60 \%, 3=60-50 \%$, $4=50-40 \%, 5=40-30 \%$. 
occurrence of ultrabasic differentiates there. The strong local variations in diorite percentages (e.g. at $\mathrm{x}-7106, \mathrm{y}-522$ ) is evidently due to differential boulder production from place to place, even if numerous erronous identifications are granted.

Considering resistant acid igneous rocks, at least 50 per cent must be allowed for background. I intentionally drew the isopleths for the background region to illustrate the lack of features there (Fig. 6). Crossing the gabbro contact in the NE part of the area, the gradient steepens, but possibly this only means that schists produce a lesser boulder fraction than does gabbro ( $c f$. Magnusson och Granlund 1928, p. 86). Comparison of Figs. 1 and 6 entitles us to state that acid igneous rocks must constitute 70 per cent or perhaps even more of the boulder fraction, before they reflect local bedrock ( $c f$. Holmes 1952, p. 1 005).

Plagioclase porphyrite and uralite porphyrite boulders form a distinct field of fans in the NW part of the counted area (Fig. 7). A part of the plagioclase porphyrite boulders derives from the porphyritic margins of the gabbro intrusive, but for the other part of these, and all uralite porphyrite boulders, no reasonable source is suggested in the geologic map (see Salli 1955). Now the aeromagnetic map entitles us to construct a belt, consisting of plagioclase porphyrites and uralite porphyrites, to link Salli's hypothetical gabbro body, situated immediately NW of the counted area, and the Taluskylä plagioclase porphyrite, $15 \mathrm{~km}$ NNW. Besides these porphyrite boulders, the ultrabasic boulders of the northern fan group (Fig. 3) may also have their provenance in this imaginary belt.

In general the counted boulders make up a representative collection of the rock types of the area. The occurrence of quartzite and limestone boulders in several counts is significant, indicating the existence of hidden horizons of such rocks in the metasedimentary sequence here. Besides the more or less common rocks, I encountered various ore types among counted

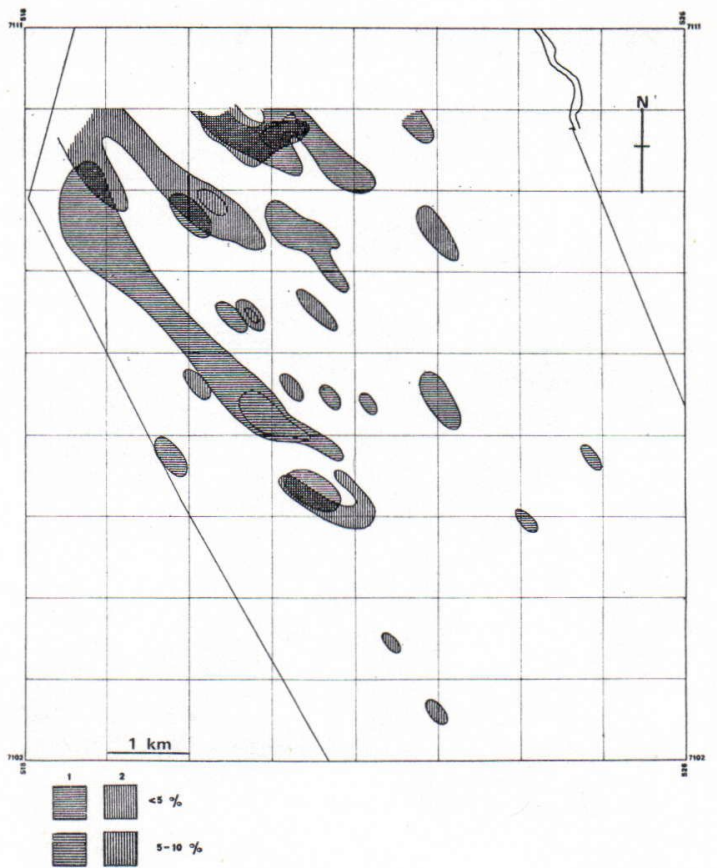

Fig. 7. Distribution of plagioclase porphyrite and uralite porphyrite boulders in till. 1 = plagioclase porphyrite, $2=$ uralite porphyrite.

boulders. Data concerning the distribution of boulders and directions of ice flow have been very helpful in solving their provenances.

\section{Influence of topography on the ice movement and till distribution. Striae}

The relief in the Ylivieska area is quite flat. Nevertheless the influence of topography on the ice movement is visible (Fig. 8), although it is not so pronounced as in areas of strong relief. Other areas which have been similarly studied are, however, much larger than in this case (cf. e.g. Holmes 1937; Gillberg 1965), therefore the topographic effects are not comparable. The present example, rather, illustrates ice movements on a small scale.

As a rule the axes of the boulder fans curve around hills and larger elevated areas. The influence of topography is particularly well documented through the pedogeochemical 


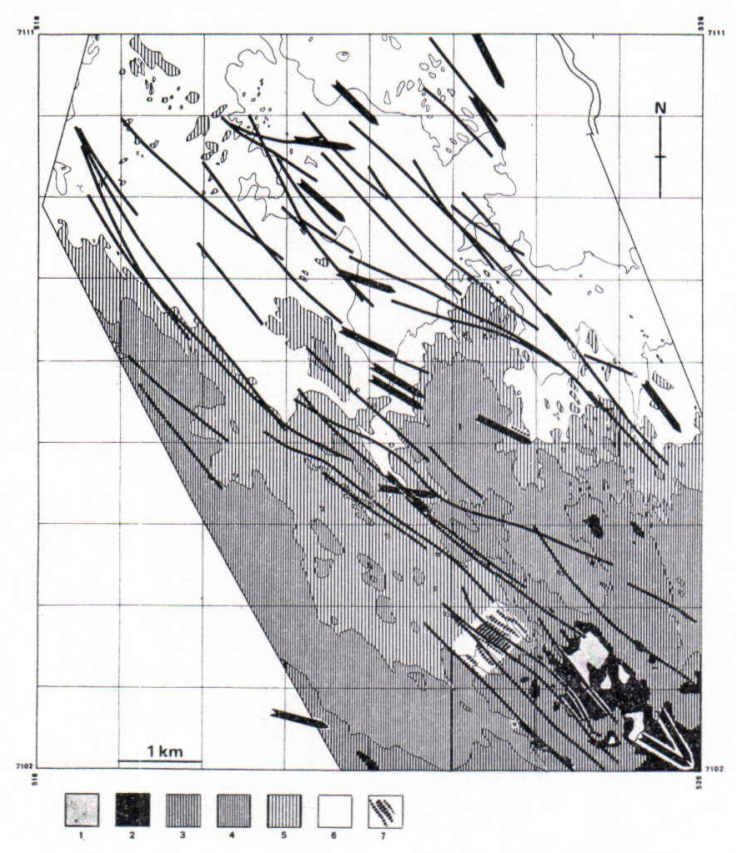

Fig. 8. Topography and ice movement directions in Ylivieska area. $1-6$ elevations above sea level: $1=>85 \mathrm{~m}$, $2=85-80 \mathrm{~m}, 3=80-75 \mathrm{~m}, 4=75-70 \mathrm{~m}, 5=70-$ $65 \mathrm{~m}, 6=>65 \mathrm{~m} .7=$ pedogeochemical anomalies Black lines $=$ axes of boulder fans. Striae shown by arrows.

anomaly strips and boulder fan axes in the southern part of the investigated area. Both diverge from a ridge, oriented parallel to the ice movement (Fig. 8).

Major and minor topographic forms are parallel to the dominant ice flow direction (see Fig. 8). These forms may be due to glacial erosion. Minor NW-oriented ridges and grooves, common in the southern and central parts of the area, may well signify glacially fluted bedrock surface. Their orientation is at the same time the trend of a pronounced fracturing (see Salli 1970), whose appearance was later accentuated by glacial erosion. Whether the relief of the bedrock surface has become more strongly developed, or whether the process has tended rather toward smoothing of former topographic irregularities (Holmes 1937; Gillberg 1967 a, p. 46), cannot be determined. Possibly the relief represents a kind of glacial erosional equilibrium.
The distribution of the till material along the course of the moving ice reflects changes in the velocity of the loaded ice base. Most local drift occurs in places where ice is stagnated by topographic obstacles (Gillberg 1965, p. 456) and (or) by severe loading (Lundqvist 1940, p. 38). In moderately loaded basal ice boulders lodge after a shortish journey. What has happened here can be traced in Fig. 8. In the north and northwest, where the topography, and presumably the bedrock surface, is rather even, the fans are long. But the plateau-like elevated unit in the middle of the area, marking the resistant central part of the gabbro intrusive, has acted as an obstacle to the loaded basal ice. At the NW border of the plateau, boulders lodged readily, as is indicated by the termination of the fan axes there ( $c f$. Holmes 1937). The whole plateau, with sparse and short fans, represents a distinct lee area (Gillberg 1965 , p. 451). There the field of basic boulders has moved very little over the gabbro intrusive ( $c f$. Figs. 1 and 2). In the SE part of the elevated area transport is worked up again. To the N-NW fan axes tend to dodge the plateau. On the SW side, again, basal ice passed rather easily through the broad valley and its gently rising head. This is the most distinct leading zone (op.cit.) here. Others are marked by the low-percentage tongues, thrusting into and penetrating the large field of basic and ultrabasic boulders (see Fig. 2). When pedogeochemical sampling is being planned or sub-outcrops as sources of ore boulders are sought, the possibility of sudden local variations in transport capacity must be taken seriously into account.

Gillberg (1967 a, p. 46, and 1967 b, pp. 408409), among others, has considered the possible sorting of the drift material according to grain size during transport. The counting method used here offers no basis for determining whether sorting took place or not. There are good reasons, though, to conclude that the decrease in size of the transported fragments downstream, though actual, is due to wear only. The crushing effect is inferred from the fans of plagioperido- 
tite and ultrabasic boulders (Figs. 3 and 4). The more rapid weakening and tapering of the ultrabasic boulder anomalies in the ice flow direction indicates simply the readier crushing of these rocks to dimensions below the counting limit, as compared to the plagioperidotite boulders. - Pedogeochemical anomalies (in till) are thought to have been caused by ore mineral grains, sometimes called microboulders, abraded from the ore outcrop (Kauranne 1959). Supposing this to hold true, the shape and symmetry of the pedogeochemical anomalies would reflect the distribution of the "primary" fine fractions in the till. Now the dimensions of the Makola nickel anomaly (see Kauranne 1959; Wennervirta 1968, Fig. 1, p. 12), situated about $35 \mathrm{~km}$ to the southeast from Ylivieska, are quite similar to those of the plagioperidotite boulder fans, presented in Fig. 4. According to this, any considerable sorting is ruled out (see also Gillberg 1965 , p. 439). In reality, though, the microboulders are partly produced through attrition during ice transport. Thus attrition, rather than sorting, explains the situation in Makola, where Kauranne (1959, pp. 3-4) has shown that the pedogeochemical anomalies caused by finer fractions are shifted farther in the direction of ice flow than are those obtained by analyzing coarser fractions.

There is a good agreement between the directions of the fan axes and striae. Both indicate local (topographically controlled) directions of ice movement (cf. Lundqvist 1935, p. 38!). In Fig. 9 observations on striae - not all shown in Fig. 8 - are collected. On each $5^{\circ}$ sector observations are coupled. The three maxima $-280^{\circ}$, $300^{\circ}$, and $330^{\circ}$ - could be interpreted to mean different phases of ice flow. The »noise» between the maxima is probably caused by topography. If only one phase existed, i.e., if all the variation in striae directions were caused by topographically controlled deflection of ice streams, the scattering in the rosette ought to be more random (Edelman 1951; see also Helaakoski 1940, p. 25). Crossing striae at $\mathrm{x}-71055, \mathrm{y}-5225$ show the

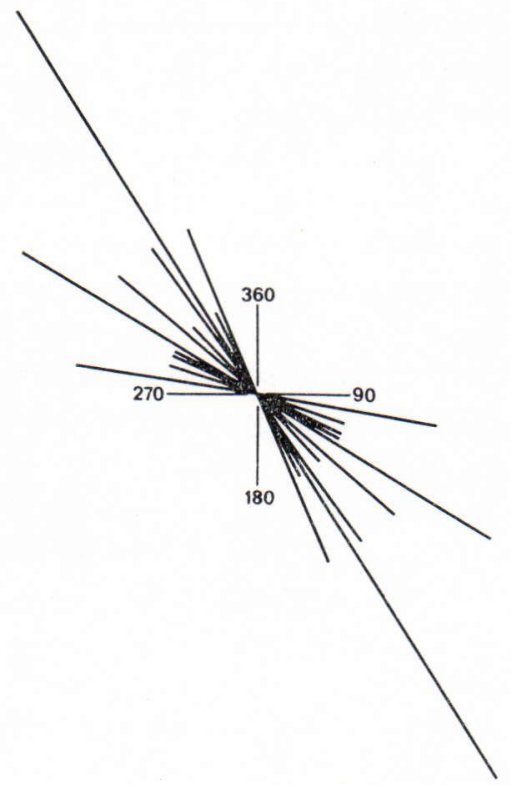

Fig. 9. Collection of striae observations. One observation $=2 \mathrm{~cm}$.

westerly direction to be older than the NW direction. Asymmetrical features in some of the boulder fans (Figs. 1 and 4) likewise give the impression of a clockwise change in the flow directions. This is consistent with other observations made in Central Pohjanmaa (Helaakoski 1940; Okko 1949, p. 18; Hyyppä 1948, pp. $111-$ 112; Mölder and Salmi 1954, p. 12; see also Lundqvist 1943, p. 9). Helaakoski (1940) found four groups of striae directions on the coast of the Gulf of Bothnia. His W-, $294^{\circ}$-, and $324^{\circ}-$ directions correspond the $280^{\circ}-, 300^{\circ}$-, and $330^{\circ}$ maxima observed by me. The figures above give the impression of a refraction-like bending of the ice sheet, moving over the coast and inlandwards. The youngest movement from the North (op.cit.; Okko 1949, p. 13) was not recorded here.

The general trend of the fan axes is about $315^{\circ}$, which is just between the two youngest striae maxima (Figs. 8 and 9). Thus it is not impossible that the two maxima mentioned might represent a single flow phase, suspected already by Helaakoski (1940, p. 19). One must bear in mind, however, that boulder fans as a general rule are 
not simple, but result from different transport events (Lundqvist 1943, p. 12), and they are not necessarily simple even here. Crossing fans (Fig. 8), as well as asymmetrical features in the boulder anomalies (Figs. 2 and 4), bear witness to such complexity. Relict fans may have been preserved in favourable places, as where stagnation has prevailed during subsequent phases of movement. Certain parts of the bedrock may have been exposed to glacial erosion only when the ice sheet flowed in some suitable direction. In this manner it is possible to explain why boulder fans in the same relatively small area may have quite divergent trends (see Sauramo 1924 , p. 13 -16). Still another important factor in the formation of boulder fans, usually neglected, is preglacial sculpturing: it is reasonable to suppose that transport is less blocked in the direction of any developed fracture system than obliquely or straight across it.

\section{Discussion and conclusions}

Counting of glacial boulders gives new and supplementary information about the bedrock lithology in poorly and (or) selectively exposed areas. Important rock groups may be entirely hidden, and glacially transported fragments are then the only readily available direct evidence of their character (see e.g. Yakovleva 1963, p. 168 and 170; Papunen 1969, pp. 151-152). For a prospector every area is both poorly and selectively exposed: he anticipates that the very rocks in which he is particularly interested, such as sulphide ores or carbonatic host rocks, will be chemically deeply weathered, and subsequently strongly scoured by the glacier. By systematic boulder counting areas critical for the occurrence of ores can be delimited and even contoured. At the same time, ore boulders are found, which might otherwise be overlooked because of their modest appearance.

Gratuitous information, concerning the behaviour of the ice sheet and drift embedded in it, is gained, such as transport directions and dis- tances, and their variations. The distribution patterns of the boulders will also give information about the crushing and grinding properties of different rock materials during transport. Where the local bedrock is known to some degree, characteristic boulder productivity for each rock type can be inferred from the isopleth maps.

In future, counting data should be prepared for computer treatment, to obtain quantitative data (see Häkli and Kerola 1966). Therefore the weighing scale should be standardized and the significance of other properties of the boulders (roundness, sphericity, etc.) scrutinized.

For regional pedogeochemical survey, data concerning the lithologic composition of till would be very valuable, both in planning the sampling and in treating and interpreting the results.

The human factor is without doubt the principal cause of errors. It is often impossible to name a rock type correctly in the field. In many instances it pays to make thin sections from commonly encountered, obscure types of rocks. When it happens, that boulders are available in abundance, instinctive selection of attractive boulders may cause their over-representation in the percentage figures.

For the present, boulder distribution data cannot be interpreted quantitatively; certain outcrops or rock types may have delivered few boulders, or none at all: the rock may have been covered by a thick preglacial weathered layer, or it may be intensively fractured. Finally some types of boulders may have decomposed on the surface during postglacial time. Pyroxenites, especially if they contain disseminated sulphides, and many coarse grained diorites, seem to do so in this investigated area.

In the light of the data presented in this paper, boulder counting is worth using as an aid to lithologic mapping under certain conditions, as when

- the mean distance the boulders have travelled is relatively short 
- boulder fans are simple or resemble such, as is the case in the Ylivieska area. Complex fans, exemplified by the Outokumpu boulder train (Okko and Peltola 1958), are undesirable for this purpose, although they provide valuable glacial geologic information.

- the lithologic units to be resolved are large enough. Delimiting the units more precisely requires that their forms are simple. That is why the boulder distribution pictures in migmatitic terrains are more or less vague (see e.g. Pääkkönen 1966).

- boulders are sufficiently available, which is not everywhere the case. This is one of the reasons why Gillberg (1965, p. 436) prefers stones in counting.
- rock types can be identified in field. This always demands petrographic training and knowledge of the local bedrock. I recommend boulders for lithologic mapping purposes; identifying stones is often difficult.

Acknowledgements - I am indebted to Prof. Kalevi Virkkala, Ph.D., head of the Dept. of Quaternary Deposits of the Geological Survey, and Mr. Risto Aario, Ph.D., Associate Professor of geology, University of Oulu, for many discussions and critical reading of the manuscript. Thanks are also due to Prof. Juhani Seitsaari, Ph.D., head of the Department of Geology, University of Oulu, for kindly reading the manuscript. Mr. Esko Sipilä, M.A., my head in the company, permitted publication of the data, for which I am grateful to him. Miss Helen C. Nisbet, M.A., B.Sc., Grant Institute of Geology, University of Edinburgh, deserves my sincere thanks for making corrections to the English.

\section{REFERENCES}

ANDERsson, S. (1964) Visingsöseriens utbredning i trakten av Finnerödja. Geol. Fören. Stockholm Förh. 86, $271-281$.

Edelman, N. (1951) Glacial abrasion and ice movement in the area Rosala-Nötö, S.W.-Finland. C.R. Soc. Géol. Finlande 24, 157-169. Bull. Comm. géol. Finlande 154.

Gillber G, G. (1965) Till distribution and ice movements on the northern slopes of the South Swedish Highlands. Geol. Fören. Stockholm Förh. 86, 433-484.

- (1967 a) Further discussion of the lithological homogeneity of till. Geol. Fören. Stockholm Förh. 89, 29-49.

- (1967 b) Distribution of different limestone material in till. Geol. Fören. Stockholm Förh. 89, 401-409.

Helaakoski, A. R. (1940) Mannerjäätikön liikuntosuunnista Pohjanmaan rannikolla ja Tampereen ympäristössä. Referat: Über die Bewegungsrichtungen des Inlandeises an der Küste von Pohjanmaa und in der Umgebung von Tampere. Fennia 67, no. 1.

Holmes, C. D. (1937) Glacial erosion in dissected plateau. Am. Jour. Sci. 33, 217-232.

- (1952) Drift dispersion in west-central New York. Geol. Soc. America Bull. 63, 993-1010.

Нучррӓ, E. (1948) Tracing the source of the pyrite stones from Vihanti on the basis of glacial geology. C. R. Soc. Géol. Finlande 21, 97-122. Bull. Comm. géol. Finlande 142.
HäKLI, T. A. and KerolA, P. (1966) A computer program for boulder train analysis. C. R. Soc. Géol. Finlande 38, 219-235. Bull. Comm. géol. Finlande 222.

Kauranne, L. K. (1959) Pedogeochemical prospecting in glaciated terrain. C. R. Soc. Géol. Finlande 31, 1-10. Bull. Comm. géol. Finlande 184.

LundQvist, G. (1935) Blockundersökningar. Historik och metodik. Sv. Geol. Unders., Ser. C, no. 390.

- (1940) Bergslagens minerogena jordarter. Sv. Geol. Unders., Ser. C, no. 433.

- (1943) Norrlands jordarter. Sv. Geol. Unders., Ser. C, no. 457.

Magnusson, N. H. och Granlund, E. (1928) Beskrivning till kartbladet Filipstad. Sv. Geol. Unders., Ser. C, no. 328 .

Mölder, K. and SALMI, M. (1954) Explanation to the map of surficial deposits B 3, Vaasa. General geological map of Finland, 1:400 000 .

Окко, V. (1949) Explanation to the map of surficial deposits B 4, Kokkola. General geological map of Finland, 1:400 000 .

- and Peltola, E. (1958) On the Outokumpu boulder train. C.R. Soc. Géol. Finlande 30, 113-134. Bull. Comm. géol. Finlande 180.

Papunen, H. (1969) Possible impact metamorphic textures in the erratics of the Lake Sääksjärvi area in south-western Finland. Bull. Geol. Soc. Finland 41, 151-155. 
PÄÄKKÖNEN, V. (1966) On the geology and mineralogy of the occurrence of native antimony at Seinäjoki, Finland. Bull. Comm. géol. Finlande 225.

SALLI, I. (1955) Kallioperäkartta, Pre-Quaternary rocks, sheet 2431, Ylivieska. Geological map of Finland, 1:100 000 .

- (1961) Kallioperäkarttojen selitys 2413-2431-2433, Kalajoki-Ylivieska-Haapavesi. English summary: Explanation to the maps of rocks. Geological map of Finland, 1:100 000.

- (1970) Kallioperän siirros- ja murrosvyöhykkeistä Keskipohjanmaalla. English summary: On the shear zones in Keskipohjanmaa, Finland. Geologi 22, 3-7.
Sauramo, M. (1924) Tracing of glacial boulders and its application in prospecting. Bull. Comm. géol. Finlande 67.

Wennervirta, H. (1968) Application of geochemical methods to regional prospecting in Finland. Bull. Comm. géol. Finlande 234.

Yakovleva, S. V. (1963)

Яковлева, С. В. (1963) Некоторые результаты изучения ледниковых валунов на югозападном побережье Ладожского озера. Тр. ВСЕГЕИ, нов. серия, т. 90, 168-177.

Manuscript received, October 8, 1970. 